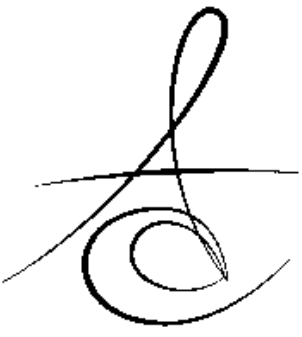

\section{EVALUATION OF STRESS DISTRIBUTION OF DIFFERENT RESTORATIVE MATERIALS IN CLASS V CAVITIES}

\section{SINIF V KAVİTELERDE FARKLI RESTORATİF MATERYALLERİN STRES DAĞILIMININ DEĞERLENDİRİLMESİ}

\author{
Dr. Öğr. Üyesi Mehmet Sami GÜLER*
}

Makale Kodu/Article code: 3512

Makale Gönderilme tarihi: 12.12 .2017

Kabul Tarihi: 19.04.2018

\section{ABSTRACT}

Aim: The aim of present study was to assess the stress distribution of different restorative materials applied in a Class V cavity by finite element analysis.

Material and Methods: A 3D tooth model of a maxillary molar tooth was created for present study. The cavity was created in the computer model. Study groups were created according to four different restorative materials (Group I: a hybrid resin-based composite, Group II: a flowable resin composite, Group III: a compomer, and Group IV: resin-modified glass ionomer cement). The von Mises stress distribution was evaluated loading of $400 \mathrm{~N}$.

Results: It was detected that the highest stress in Group II (301.21 MPa). However, it was observed that the lowest stress in Group I (235.74 MPa).

Conclusion: Within the limitations of our study, the lowest stress distribution for Class $\mathrm{V}$ cavity was obtained in the hybrid composite resin.

Keywords: Finite element analysis, restorative materials, stress distribution

\section{öz}

Amaç: Bu çalışmanın amacı sonlu elemanlar analizi ile Sınif V kavitede uygulanan farklı restoratif materyallerin stres dağııımını değerlendirmektir.

Gereç ve Yöntem: Çalışma için bir maksiller sol birinci molar dişin üç boyutlu diş modeli oluşturuldu. Kavite bilgisayar ortamında hazırlandı. Dört farklı restoratif materyale göre çalışma grupları (Grup I: hibrid kompozit rezin, Grup II: akıc kompozit rezin, Grup III: kompomer ve Grup IV: rezin modifiye cam iyonomer siman) oluşturuldu. $400 \quad$ N'luk yük uygulanarak Von Mises stres dağııımı değerlendirildi.

Bulgular: En yüksek stres Grup II'de (301,21 MPa) tespit edidi. Bununla birlikte, en düşük stres Grup I'de (235,74 MPa) gözlendi.

Sonuç: Çalışmamızın sınırları dahilinde, Sınıf V kaviteler için en düşük stres dağıımı hibrit kompozit rezinde elde edilmiştir.

Anahtar Kelimeler: Sonlu elemanlar analizi, restoratif materyaller, stres dağıııı

\section{INTRODUCTION}

Tooth decay may cause pain, infection, necrosis of pulp, and ultimately the loss of the tooth. It is the most prevalent infectious disease in children, as well as in adults. ${ }^{1-4}$ In addition, can be treated with various restorative materials and different restorative application techniques and cavity preparation methods. Today, the use of aesthetically pleasing materials has increased in response to patient demand. However, clinicians should consider not only the aesthetics of the restorative material but also its biomechanics and durability when choosing the most appropriate material. $^{5}$

Restored teeth are exposed to mechanical stress at different levels since occlusal forces, and the durability of the restorations mostly depends upon these stresses. The finite element analysis (FEA) method, which uses advanced computing and modeling techniques, provides a reliable means of

\footnotetext{
*Ordu Üniversitesi, Teknik Bilimler Meslek Yüksekokulu, Makine ve Metal Teknolojileri Bölümü, Ordu
} 
determining the biomechanics of restorative materials. Computer-aided quantitative studies have also become a very important tool in dentistry, particularly in the identification of the source of failure, offering satisfying and reliable results when combined with FEA. In addition, experiments that could not be performed on patients can be done in the computer environment using FEA. Moreover, analyzing the durability of the restorative materials when exposed to occlusal forces by this method could be quick and cost-effective. $^{6-8}$

Conventionally, cervical lesions, both carious and noncarious, have been treated with a Class $\mathrm{V}$ cavity preparation using different restorative materials. $^{9}$ However, premature loss of Class V restorations of cervical lesions is very common. ${ }^{10}$ There are very few study about stress analyses of Class V cavities under occlusal forces using FEA. ${ }^{11-15}$ In the studies that have been conducted, the mandibular premolar tooth were mostly modeled. ${ }^{11-14}$ Yaman et al. ${ }^{15}$ performed FEA of a Class $\mathrm{V}$ cavity on the anterior tooth. The stress distribution of different restorative materials at Class $\mathrm{V}$ cavities on the maxillary molar teeth using FEA has been limited. ${ }^{9}$

The purpose of this research was to conduct a stress analysis of different restorative materials at Class $\mathrm{V}$ cavities on the maxillary molar tooth using FEA. Research hypothesis in present study is von Mises stress distribution at Class $V$ cavities on the maxillary molar teeth would be not affected by type of restorative materials.

\section{MATERIALS AND METHODS}

\section{Modeling of teeth}

An extracted maxillary left first molar tooth was used for the 3D tooth model. The 3D tooth model procedures were made according to Guler et al. ${ }^{9}$ and Gurbuz et al. ${ }^{16}$ recommendations (Fig. 1).

\section{Meshing}

Mesh (72.621 elements and 104.665 nodes) was obtained automatically using the ANSYS 13 Workbench (Swanson Ansys Inc., Houston, USA). Figure 2 is shown the meshed model and preparation of Class V cavity.

\section{Preparation of the cavity}

The Class $\mathrm{V}$ cavity ( $3 \mathrm{~mm}$ mesio-distally, 2.5 $\mathrm{mm}$ gingivo-occlusally, and $2 \mathrm{~mm}$ in depth) was prepared in the computer model.

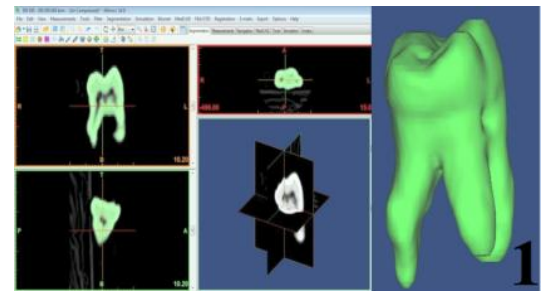

Figure 1. Three-dimensional model.

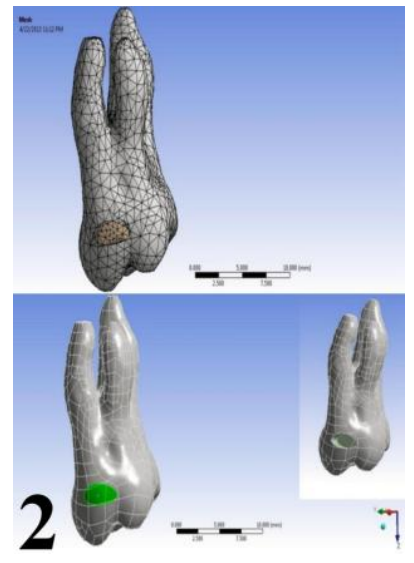

Figure 2. The meshed model and preparation of Class $\mathrm{V}$ cavity.

\section{Load}

First, three-dimensional tooth model was created and meshed. Second, the cavity was prepared. Then, the cavity was restored with four restorative materials in the computer model and divided into the following four groups:

Group I - The first model was restored with a hybrid resin-based composite (Valux Plus, 3M ESPE, St. Paul, MN, USA).

Group II - The second model was restored with a flowable resin composite (Tetric Flow, Ivoclar Vivadent, Schaan, Liechtenstein).

Group III - The third model was restored with a compomer (Dyract AP, Dentsply/De Trey, Konstanz, Germany).

Group IV - The fourth model was restored with resin-modified glass ionomer cement (GC Fuji II LC, GC Corporation Tokyo, Japan).

Table 1 presents the mechanical properties of restorative materials used in present study. ${ }^{15,16}$ Loads of $400 \mathrm{~N}$ were applied on the restorative material at an angle of $45^{\circ}$. The von Mises stress distribution was calculation using ANSYS 13 Workbench software.

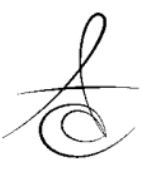


Table 1. Mechanical properties of restorative materials and teeth

\begin{tabular}{ccc}
\hline Materials & $\begin{array}{c}\text { Elastic modulus } \\
\text { (MPa) }\end{array}$ & $\begin{array}{c}\text { Poisson's } \\
\text { ratio }\end{array}$ \\
\hline Enamel & 48000 & 0.33 \\
\hline Dentin & 13000 & 0.31 \\
\hline $\begin{array}{c}\text { Hybrid resin-based } \\
\text { composite }\end{array}$ & 19700 & 0.24 \\
\hline Flowable resin composite & 5300 & 0.28 \\
\hline Compomer & 10700 & 0.28 \\
\hline $\begin{array}{c}\text { Resin-modified glass } \\
\text { ionomer cement }\end{array}$ & 10860 & 0.3 \\
\hline
\end{tabular}

\section{RESULTS}

Table 2 presents the maximum von Mises stress values recorded for study groups. Figure 3 presents the von Mises stress distribution of the study groups. Among the groups, the highest stress value was $301.21 \mathrm{MPa}$, which was obtained when the Tetric Flow was used (Group II). The lowest von Mises stress value was $235.74 \mathrm{MPa}$, which was obtained when the Valux Plus was used (Group I).

Table 2. The von Mises stress values

\begin{tabular}{cc}
\hline Study Groups & von Mises Stress Values (Mpa) \\
\hline Group I & 235.74 \\
\hline Group II & 301.21 \\
\hline Group III & 280.08 \\
\hline Group IV & 278.05 \\
\hline
\end{tabular}

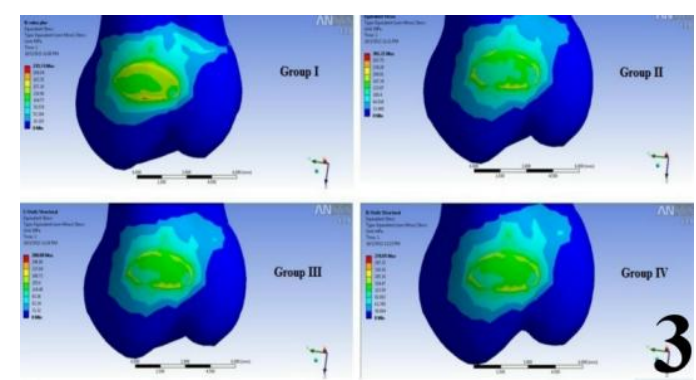

Figure 3. The distribution of von Mises stress according to groups.

\section{DISCUSSION}

The type, elastic modulus, and rigidity of restorative material are very important to the toothrestorative material interface bonding. Many factors, such as the type of the restorative material, the design of the cavity, and the adhesive resistance between the restorative material and the teeth, affect the stress that occurs on restored teeth. ${ }^{17}$ Therefore, to determine the stress on restored teeth, experimental studies need to use different restorative materials, cavity designs, loads, and load angles. In the present study, the stress distribution of four restorative materials in a Class $V$ cavity was analyzed by FEA. The results revealed that von Mises stress distribution at Class $\mathrm{V}$ cavities on maxillary molar teeth was affected by type of restorative materials. Thus, the null hypothesis was rejected.

Some problems may occur in Class $\mathrm{V}$ restoration when applying the restorative materials or the ending of the edges of cervical cavity at the margin of the dentin. ${ }^{9,10,14}$ Hybrid resin-based composites, compomers, flowable resin composites, glass ionomers, or resin-modified glass ionomer cements are used frequently in the restoration of Class $\mathrm{V}$ cavities. ${ }^{9,14}$ Although the mechanical properties of resin composites have been improved during the past few years, the adhesion of the restoration may still be insufficient because of a lack of insulation and polymerization shrinkage. ${ }^{14,18}$ Moreover, the restorative material may shrink after the resin composite has been placed in the cavity due to physical and chemical changes. ${ }^{19,20}$ The microgap that forms between the restorative material and the cavity wall can also allow the passage of oral fluid, bacteria, air, molecules, and ions, resulting in microleakage between the cavity wall and the restoration. ${ }^{21}$ This microleakage may cause discoloration of the margin and affect the integrity of the margin as well as causing secondary decay, postoperative sensitivity, and pulp necrosis. ${ }^{22}$ Folwaczyn et al. ${ }^{10}$ found that composite restorations provided successful results in the treatment of cervical lesions over a 2-year period.

Glass ionomer cements have been used for years as a restorative material in the restoration of cervical lesions. This material is biocompatible, bonds easily to the hard tissues of the tooth, and has fluoride release close to that of tooth tissue. ${ }^{23}$ Its thermal expansion coefficient is also close to that of tooth tissue. $^{23}$ Despite these favorable properties, poor physical and aesthetic properties and susceptibility to moisture during the hardening process have diverted research towards developing alternative materials. Thus, resin-modified glass ionomer cement and compomers have been produced. ${ }^{24}$ De Magelhäes et al. ${ }^{25}$ reported that compomers, conventional glass ionomer cements, and composites in Class $\mathrm{V}$ cavities 
have similar in vitro leakage performance. Brackett et $a^{26}$ found no significant differences in the clinical success of compomers and resin composites in a Class $\mathrm{V}$ cavity over a 2-year period. Yaman et al. ${ }^{15}$ reported that maximum von Mises stress in Class $V$ cavities occurred with a flowable resin composite. In the our study, the stress values of the compomer, resinmodified glass ionomer cement, and hybrid resinbased composite were similar. The flowable resin composite had the highest stress value. Yaman et al. ${ }^{15}$ also reported that the stress increased when there was a disparity between the elastic modulus of the enamel and the restorative material. The results of our study corroborate those of Yaman et al. ${ }^{15}$

In vivo studies have reported different findings on occlusal forces at the posterior region. Tortopidis et al. ${ }^{27}$ reported that the maximum biting force is $580 \mathrm{~N}$ at the posterior region in a healthy human. However, Bakke et al. ${ }^{28}$ reported that the maximum biting force (males $522 \mathrm{~N}$ and females $441 \mathrm{~N}$ ) is different for males and females. In addition, $\mathrm{Fu}$ et al. ${ }^{29}$ reported that the biggest occlusal force can achieve $480 \mathrm{~N}$ for the maxillary first molar. Considering all these reports, $400 \mathrm{~N}$ was used as the occlusal load in present study. Using of different occlusal load may cause different von Mises stress distribution.

Yaman et al. ${ }^{15}$ reported that when the loading angle, the restorative material, and the restoration size remained fixed, increasing the load amplified the von Mises stress distribution in the tooth and the restoration. In the present study, the load was applied on the restorative material at an angle of $45^{\circ}$. Different loads and load angles may change the von Mises stress value.

Asmussen and Peutzfeldt ${ }^{7}$ reported that, it has been expressed that the observed high stress values in the region where the force was applied are due to the intense force. Therefore; this should be taken into consideration when interpreting data in finite element study. In addition, when the elastic modulus of enamel and restorative material is different, greater stresses will occur as the structural continuity of the tooth is mechanically different. ${ }^{15}$ The highest von Mises stress values found for the present study, which has the wider stress ranges, ranked as follows: Group II > Group III> Group IV> Group I. The lowest stress values were obtained in Group I (hybrid resin-based composite) which was restored with materials having an elastic modulus close to that of enamel. The highest stress values were obtained in Group II (flowable resin composite) which were restored with materials having an elastic modulus far from the enamel. The results of our study corroborate those of Sengul et al. ${ }^{30}$ They reported that a restorative material with appropriate elastic modulus, able to balance stress concentrations. ${ }^{30}$ In this way, should be used to increase the survival rate restorative materials.

The search for an ideal filling to combat mechanical and thermal stresses and to provide optimum aesthetic results is ongoing. At the same time, manufacturers are developing new products with altered adhesive properties and new restorative materials. Due to these rapid developments, it is becoming more difficult to test these materials in vivo. Although it is vital to test the possible success of these materials in vitro, laboratory models cannot completely replicate the oral environment and patients' behavior. Thus, in vivo studies have to be supported with in vitro ones to obtain a better evaluation of the clinical success and the physical properties of the restorative materials. Our study results should be supported by further in vivo and in vitro studies.

\section{CONCLUSIONS}

Within the limitations of this study, the following conclusions may be drawn:

1- The lowest stress was obtained with a Valux Plus in a Class $\mathrm{V}$ cavity.

2- The highest stress was obtained with a Tetric Flow.

3- The use of a hybrid-resin based composite in a Class $\mathrm{V}$ cavity could improve the clinical success rate.

\section{Financial Disclosure}

This study was not supported by institutional, private and corporate financial support.

Conflict Of Interest

No conflicts of interest.

Mehmet Sami GÜLER: ORCID ID: 0000-0003-0414-7707 


\section{REFERENCES}

1. No authors listed. Oral health in America: a report of the Surgeon General. J Calif Dent Assoc 2000; 28: 685-95.

2. Lima YB, Cury JA. Seasonal variation of fluoride intake by children in a subtropical region. Caries Res 2003; 37: 335-8.

3. Ana PA, Bachmann L, Zezell DM. Lasers effects on enamel for caries prevention. Laser Physics 2006; 16: 865-75.

4. Rodrigues LKA, Santos MN, Pereira D, Assaf AV, Pardi V. Carbon dioxide laser in dental caries prevention. J Dent 2004; 32: 531-40.

5. Cortellini D, Canale A, Giordano A, Bergantini B, Bergantini $\mathrm{D}$. The combined use of all-ceramic and conventional metal-ceramic restorations in the rehabilitation of severe tooth wear. Quint Dent Technol 2005; 28: 205-14.

6. Lee $\mathrm{HE}$, Lin $\mathrm{CL}$, Wang $\mathrm{CH}$, Cheng $\mathrm{CH}$, Chang $\mathrm{CH}$. Stresses at the cervical lesion of maxillary premolar-a finite element investigation. J Dent 2002; 30: 283-90.

7. Asmussen E, Peutzfeldt A. Class I and Class II restorations of resin composite: an FEM analysis of the influence of modulus of elasticity on stresses generated by occlusal loading. Dent Mater 2008; 24: 600-5.

8. Güler MS, Şen S, Bayındır YZ, Güler Ç. İnsan dişi kaplamalarinda kullanilan farkli özelliklerdeki yapiştirici simanlarin gerilme dağilimina etkilerinin sonlu elemanlar yöntemi ile incelenmesi. Atatürk Üniv Diş Hek Fak Derg 2012; 22: 31-9.

9. Guler MS, Guler C, Cakici F, Cakici EB, Sen S. Finite element analysis of thermal stress distribution in different restorative materials used in Class $\mathrm{V}$ cavities. Niger J Clin Pract 2016; 19: 30-4.

10. Folwaczny $M$, Loher $C$, Mehl A, Kunzelmann $\mathrm{KH}$, Hinkel R. Toothcolored filling materials for the restoration of cervical lesions: a 24- month followup study. Oper Dent 2000; 25: 251-8.

11. Vasudeva G, Bogra P, Nikhil V, Singh V. Effect of occlusal restoration on stresses around Class $V$ restoration interface: a finite-element study. Indian J Dent Res 2011; 22: 295-302.
12. Rees JS, Jacobsen PH. The effect of interfacial failure around a Class $\mathrm{V}$ composite restoration analysed by the finite element method. J Oral Rehabil 2000; 27: 111-6.

13. Rees JS, Jacobsen PH. The effect of cuspal flexure on a buccal Class $V$ restoration: a finite element study. J Dent 1998; 26: 361-7.

14. N S, N M, Shetty A, Kumari A, DN N. Finite element analysis of stress concentration in Class $V$ restorations of four groups of restorative materials in mandibular premolar. J Conserv Dent 2008; 11: 121-6.

15. Yaman SD, Sahin M, Aydin C. Finite element analysis of strength characteristics of various resin based restorative materials in Class $\mathrm{V}$ cavities. J Oral Rehabil 2003; 30: 630-41.

16. Gurbuz T, Sengul F, Altun C. Finite element stress analysis of short-post core and over restorations prepared with different restorative materials. Dent Mater J 2008; 27: 499-507.

17. Hood JAA. Biomechanic of intact, prepared and restored tooth: some clinical implications. Int Dent J 1991; 41: 25-32.

18. Amore R, Pagani C, Youssef MN, Anauate Netto C, Lewgoy HR. Polymerization shrinkage evaluation of three packable composite resins using a gas pycnometer. Pesqui Odontol Bras 2003; 17: 273-7.

19. Manhart J, Garcia-Godoy F, Hickel R. Direct posterior restorations: clinical results and new developments. Dent Clin North Am 2002; 46: 30339.

20. Sparrius O, Grossman ES. Marginal leakage of composite resin restorations in combination with dentinal and enamel bonding agents. J Prosthet Dent 1989; 61: 678-84.

21. Roberson TM, Heymann HO, Swift EJ Jr. Sturdevant's Art and Science of Operative Dentistry. 5 ed. St Louis; Mosby: 2006. p. 245-79.

22. Sarrett DC. Clinical challenges and the relevance of materials testing for posterior composite restorations. Dent Mater 2005; 21: 9-20.

23. Mclean JW, Nicholson JW, Wilson AD. Proposed nomenclature for glass-ionomer dental cements and related materials. Quintessence Int 1994; 25: 587-9. 
24. Hickel R, Dasch W, Janda R, Tyas M, Anusavice K. New direct restorative materials. FDI commission project. Int Dent J 1998; 48: 3-16.

25. De Magalhäes CS, Serra MC, Rodrigues Jr AL. Volumetric microleakage assessment of glassionomer-resin composite hybrid materials. Quintessence Int 1999; 30: 117-21.

26. Brackett WW, Dib A, Brackett MG, Reyes AA, Estrada BE. Two-year clinical performance of Class $\mathrm{V}$ resin-modified glass ionomer and resin composite restorations. Oper Dent 2003; 28: 47781.

27. Tortopidis D, Lyons MF, Baxendale RH, Gilmour $\mathrm{WH}$. The variability of bite force measurement between sessions, in different positions within the dental arch. J Oral Rehabil 1998; 25: 681-6.

28. Bakke M, Michler L, Moller E. Occlusal control of mandibular elevator muscles. Scand J Dent Res 1992; 100: 284-91.

29. Fu G, Deng F, Wang L, Ren. The three-dimension finite element analysis of stress in posterior tooth residual root restored with postcore crown. Dent Traumatol 2010; 26: 64-9.

30. Sengul F, Gurbuz T, Sengul S. Finite element analysis of different restorative materials in primary teeth restorations. Eur J Paediatr Dent 2014; 15: 317-22

\section{Yazışma Adresi}

Dr. Öğr. Üyesi Mehmet Sami Güler Ordu Üniversitesi, Teknik Bilimler Meslek Yüksekokulu, Makine ve Metal Teknolojileri Bölümü, 52200 Ordu

Telefon: 4522334865 (iş)

Faks : 4522335230

E-mail: mehmetsamiguler@yandex.com 